\title{
Value-Action Gap in Climate Change Amongst Indonesians
}

\author{
Ardhi Arsala Rahmani ${ }^{1}$ \\ School of Government and Public Policy (SGPP), Bogor, Indonesia

\section{Muhammad Ery Wijaya} \\ School of Government and Public Policy (SGPP), Bogor, Indonesia
}

\section{Fajar B. Hirawan}

School of Government and Public Policy (SGPP), Bogor, Indonesia

\author{
Received : 17 November 2020 \\ Accepted : : 2 November 2021 \\ Available Online : 31 December 2021
}

\begin{abstract}
The problem of climate change is defined by continued sea-level rise, melting of the ice caps, and increasing global temperatures. However, despite increasing informational awareness towards these facts by government and grassroots advocacy in many countries, emissions as the leading determinant of climate change continue to rise, with the growing consumption and activities being major emitters. In behavioral studies, this gap between perceived concerns and reflected actions is called the 'value-action gap' (VAG). This research evaluates the existence of a VAG among the Indonesians as increasingly significant emitters. Therefore, this research aims to determines whether relationships exist between climate change knowledge, reported concerns, and exhibited actions taken to mitigate climate change. The research proposes the hypotheses that concerns and awareness of climate change are high among the studied population, but do not influence high climate behavior. The research gathers three class variables through a quantitative sampling, namely climate change knowledge, climate change concerns, and climate change behaviors. The gap is then calculated as a subtraction score between the latter two variables. Moreover, discrepancies between the actions taken and reported concerns are assessed, showcasing policy implications going forward. The findings of this research based on the sample suggest that varying income groups of urbanite households hold significant knowledge of climate change and have reported concerns towards the issue, and that the two as variables are linked to each other.
\end{abstract}

Keywords: climate behavior; climate concern; value-action gap; structural-equation modeling

\section{Introduction}

At a global level, numerous polls have indicated that most of the world's population is aware of climate change (Leiserowitz, 2007; World Bank, 2009; Stokes et al., 2015; Fagan \& Huang, 2019). The awareness, which the respective surveys would variously define, all

\footnotetext{
${ }^{1}$ Corresponding Author: School of Government and Public Policy (SGPP), Bogor, Indonesia

Email: a.rahmani@sgpp.ac.id 


\section{Value-Action Gap in Climate Change Amongst Indonesians}

sum up as a measure of the respondent acknowledgment of the phenomenon. With the different methodologies of the polls and the questions asked, Indonesia's respondents reflect the nation as climate change awareness in some polls (World Bank, 2009; Fagan \& Huang, 2019) and as deniers in another (YouGov, 2019). However, as rising emissions cause further deterioration to the atmospheric balance, i.e., climate change (IPCC, 2018), Indonesia sits as one of the largest emitters of greenhouse gases (Dunne, 2019).

That said, Indonesia as a global contributor to climate change, is burdened with the responsibility to partake in reducing its emissions should atmospheric balances be aimed for-and as of the Paris Agreement, Indonesia has committed to reducing at least $29 \%$ of its emissions on its measures and up to $41 \%$ through conditional international assistance by 2020 against a business-as-usual scenario (GGGI-Bappenas, 2019). This commitment, otherwise dubbed the Nationally Determined Contribution (henceforth NDC) was a politically high-level established commitment that aimed to limit global temperature rise below $2^{\circ} \mathrm{C}$ with further efforts up to $1,5^{\circ} \mathrm{C}$ (IPCC, 2018). Yet, the political elites may convey climate commitments in international negotiation tables, but whether emission reductions materialize comes down to the effective implications in the respective states and affect the emitters at the micro-level. Specifically, with regards to the consumption patterns that lead to emissions.

The underlying logic is that if consumption patterns can be tweaked so that unsustainable consumption behaviors are ameliorated at the individual and household level, then there is a prospect for sustainability transformation that could go in tandem with supply-side projects (e.g. the production of new and renewable energy) which would take more time (Norton et al., 1998; Kollmuss \& Agyeman, 2002; Newton \& Meyer, 2013). Consequently, just as some supply-side policies have their hurdles (e.g. costs and time periods), the demand-side ideas are easier said than done (Blake, 1999). Thus, when looking back to the beginning paragraph where various polls for Indonesia indicate two different perceptions of climate change, it would be increasingly difficult to introduce demand-side changes should the denier nation attribute ring truer than the other. This is a logical consequence of denialism going against measures that would otherwise interfere individual utility preferences (in this case as fossil fuel consumerist) whom the policies would target (Brown \& Cameron, 2000).

Yet, besides the dichotomy of denialism and acceptance, the surveys on concerns about climate change in many countries show that they do not necessarily translate to greenhouse gas mitigation practices. At the same time, global temperature targets would require an accelerated supply-side change for emissions and sustainability transformations at the individual and household demand levels (Newton \& Meyer, 2013; Rahman et al., 2019). As for Indonesia specifically, state-wide climate perceptions are conflicting, but a sizeable middle-class is shown to be aware of the phenomenon, as stated in Ipsos (2019). That said, since the Ipsos (2019) document does not establish the details of middle-class climate awareness and how far they are knowledgeable about the issue, the statement need not be taken at face value. Instead, two problems can be derived from the account in Ipsos (2019) and the preceding background.

The above condition implies that consumption patterns are inhibited by "structural, cultural, social and institutional" factors. Such factors would create gaps between formed values expressed as concerns and the stated social, economic, ethical, or environmental issues and actions or decisions upon such concerns. This observed discrepancy between an individual has expressed environmental concern and decisions impacting the environment in practice is termed the 'value-action-gap' (Babutsidze et al., 2018; Barr, 2006; Blake, 1999; Chai et al., 2015; Chaplin \& Wyton, 2014; Chung \& Leung, 2007; Flynn et al., 2009). Other literature term the phenomenon as 'attitude-behavior gap', 'awareness-behavior gap,' 'attitude-action gap' or environmental values-behavior gap' (Bai \& Liu, 2013; Kennedy et 
al., 2009; Kollmuss \& Agyeman, 2002; Newton \& Meyer, 2013). In any case, the underlying interpretation of the term across literatures is succinctly phrased in Blake (1999), which states:

"[the value action-gap] in general terms [are] the differences between what people say and what people do" (Blake, 1999).

In the words of Flynn et al. (2009), the gap is evident when '[p]eople express strong support for environmentally sustainable policies, but display little commitment to alter their own behavior'. The authors showcased this with results of the British Social Attitudes survey which highlights the disparity between increasing levels of environmental concerns with unsustainable energy consumption as exemplified in increasing air travel and automobile use (Flynn et al., 2009). When considering that shifting energy consumption behavior is important to achieve efficiency, such gaps serve as significant barriers (Rahman et al., 2019), and that attempts to promote general awareness and concerns may be insufficient on their own.

In that study by Blake (1999), explorations are done on the value-action gap concerning sustainability and environmental practices in the United Kingdom. Through 163 detailed face-to-face interviews with individuals in Huntingdonshire, Blake (1999) that 'environmental concern, and basic environmental action (such as recycling), are now becoming widespread throughout the population; but few people take environmental actions that involve changes their lifestyle.' Against the backdrop of the UK Government's Going for Green (GFG) initiative, which is set up as an environmental awareness campaign to enable environmental behavior, Blake (1999) argues that policies subscribing to an information deficit model (i.e., presuming people do not have enough information) will face a barrier, which is the evident 'value-action gap.' Blake (1999) further argues that the barriers that hold back action are categorized into three: individuality, responsibility, and practicality.

Another inquiry into the 'value-action gap' amongst Britons is found in Barr (2006), who studied waste minimization behavior in Exeter, Devon. Formed as a part of a large research project on waste management behavior in 1999, Barr (2006) quantitatively assessed waste management behavior, behavioral intentions and held environmental values against situational variables and psychological variables through a questionnaire delivered across random households $(\mathrm{N}=673)$ in Exeter. Barr (2006) assessment showcases that the value-action gap is explained by elements of the social behavior model formulated by Fishbein and Ajzen (1975), where relations between stated intention and behavior differ. People reported their willingness to minimize waste regularly, yet waste minimization in Exeter was relatively low. Barr (2006) adds that with regards to waste minimization, 'governmental awareness campaigns are unlikely to be effective in shaping this behavior since individuals are already aware of the need to recycle'.

Further research that explores the gap in the quantitative direction is found in (Bai \& Liu (2013), who assesses the link between low-carbon awareness and behaviors of residents in Tianjin, People's Republic of China $(\mathrm{N}=354)$. Low-carbon awareness in their study is based on the concept of environmental awareness, which includes low-carbon knowledge as an important construct. Through a questionnaire, Bai \& Liu (2013) assessed the resident's by an instrument that included seven scales with 26 -items, namely public and private low-carbon behavior; (adapted from Stern, 2000); low-carbon value (adapted from Thompson \& Barton, 1994); low-carbon attitude (based on the New Ecological Paradigm in Dunlap et al., 2000); low-carbon knowledge (based on Schahn \& Holzer, 1990); barriers and motivators of low-carbon behaviors (based on Stern, 2000). Their SEM analysis suggests that low-carbon knowledge directly affects public and private low-carbon behavior, whilst being insignificant by indirect effects through attitudes and values. In contrast to the 
previous literatures, their findings showcase that a gap exists, however with reported behaviors being higher than awareness levels (Bai \& Liu, 2013).

In Chai et al. (2015) a scale is developed to empirically measure the gap itself by calculating the difference between rescaled constructs of concern and behavior that were expressed in percentage terms between 0 and 1 . The authors, who write on the role of discretionary time in sustaining climate change value-action gap, used responses from a 120-items online web-based survey that recorded climate change knowledge, experiences, attitudes, concerns and sustainable consumption practices in Australia which were conducted by (Reser et al., 2012). By having the value-action gap score as the dependent variable, the authors find that individuals with relatively more discretionary time available to them shows lesser value-action gap. An interesting finding however is that reported knowledge showcased reduced value-action gap, yet concern about climate change had the opposite effect (Chai et al., 2015).

Finally, Similar to Chai et al. (2015), the literature by Babutsidze et al. (2018) inquires upon the value-action gap by providing an empirical measure of the gap itself using the same formula of calculating the difference between rescaled constructs of concern and behavior that were expressed in percentage terms between 0 and 1 . Their study which was on overall public perceptions and responses to climate change across France showcased varying levels of climate change beliefs, acceptance, concerns, perception, knowledge, actions and gaps. Babutsidze et al., (2018) finds that those "who reported the highest levels of concern only participated in an average of $62 \%$ of the possible climate mitigation actions listed'. Against socio-demographic variables, the authors also find that students reported the highest level of value-action gap, where levels of mitigation behavior were low despite high level concerns (Babutsidze et al., 2018).

From the literatures mentioned before, it shows that in various countries the valueaction gap exists amongst individuals with varying explanations for their reasons according to select approaches and models. However, none of the literatures mentioned above have addressed the Indonesian populace, namely whether there is a discrepancy between reported actions and stated concern. Hence this study aims to determine the levels of climate knowledge and concerns amongst Indonesians and behaviors reported that mitigate or adapt to climate change, and then assess the gaps between reported concerns and actions exhibited as done in Australian sample of Chai et al., (2015) as well as the French sample of (Babutsidze et al., 2018).

\section{Research Methods}

Given the background problem and previous research that have been conducted on the matter, this research first measured the levels of climate knowledge and concerns amongst Indonesians and actions taken that mitigate or adapt to climate change through a survey-based self-reporting. Following such assessments, discrepancies between the reported concerns and behaviors were measured to determine the levels of gaps Indonesians indirectly reported.

Our hypothesis assumes an initial linear path model Bai \& Liu (2013); Barr (2006); Kollmuss \& Agyeman (2002) in that there is a direct and indirect effects of climate change knowledge upon climate change concerns, and climate change behavior with a measurement of value-action gap. The following research hypotheses in detail are therefore formulated: $\mathrm{H} 1=$ climate change knowledge affects climate change concern directly; $\mathrm{H} 2=$ climate change knowledge affects climate change behavior directly; $\mathrm{H} 3$ = climate change concern affects climate change behavior directly; and $\mathrm{H} 4=$ Climate change knowledge affects climate change behavior indirectly via climate change concern. Then, following a standardized difference between concern scores and behavior scores as done by Chai et al., 
(2015) and Babutsidze et al., (2018), the inclusion of the measured gap forms these additional hypotheses: $\mathrm{H} 5$ = climate change knowledge affects value-action gap directly; $\mathrm{H} 6$ = climate change concern affects value-action gap directly; and $\mathrm{H} 7$ = climate change knowledge affects value-action gap indirectly via climate change concern.

Furthermore, the assessment of data utilizes a Structural Equation Modelling (SEM) statistical technique to model the relationships between observed variables and latent variables as well as concurrent interdependencies between them (Bai \& Liu, 2013). The use of SEM is considered to be appropriate given the latencies of the variables which are explained below. The software LISREL is used to model the structures and equation. Findings from the SEM analysis result uncovers the extent of the relationship to which respondents are knowledgeable and concerned about climate change as well as the gaps in their reported actions. The data gathered to be processed in SEM are acquired with a quantitative survey through structured questionnaire distribution and qualitative online interview. The primary data serves as the main information to be used for the purposes of this research. The self-administered questionnaire is distributed online directly to respondents via the Google Forms platform. The questionnaire was developed in Bahasa Indonesia to reflect the targeted audience's native language and for the purposes of feasibility. The core section of the questionnaire contains the elements that are divided into three subsections representing each latent variable to be assessed.

\section{Variable 1: Climate Knowledge (CK)}

Based on various literatures, the variable climate knowledge is defined as the "Knowledge of the causes, consequences and potential solutions to global climate change and with respect to Indonesia" (Reser et al., 2012; Salehi et al., 2016).

\section{Variable 2: Climate Concern (CC)}

Concern on climate change "relates to the risk perception and sense making with respect to perceived environmental changes and threats" (Reser et al., 2012).

\section{Variable 3: Climate Behavior(CB)}

Climate change behaviors refers to indicated actions that reduce carbon footprint and therefore mitigate climate change (Reser et al., 2012).

\section{Variable Operationalization}

As latent variables are not directly observable, measurable indicators are used, and is reflected in the questionnaire items constructed for the respective variables (Kline, 2015). The climate change knowledge and climate change concern subsections include statements with Likert-scale responses, whereas the climate change behavior include checkbox options of different practices that respondents pick. The details of each construct variables and their questionnaire items are available in Table 1.

Table 1. Constructs and Items

\begin{tabular}{|c|c|c|c|}
\hline $\begin{array}{l}\text { Construct } \\
\text { Variable }\end{array}$ & Items & Source & Scale \\
\hline $\begin{array}{l}\text { Climate } \\
\text { Knowledge (CK) }\end{array}$ & $\begin{array}{l}\text { CK1: Carbon dioxide in the atmosphere } \\
\text { increases the greenhouse effect } \\
\text { CK2: Increasing greenhouse effect results } \\
\text { in global warming }\end{array}$ & $\begin{array}{l}\text { Adapted from } \\
\text { Salehi, Nejad, } \\
\text { Mahmoudi, \& } \\
\text { Burkart (2016) }\end{array}$ & $\begin{array}{l}\text { Likert } 1-5 \\
(1=\text { Strongly } \\
\text { Disagree until } 5 \\
=\text { Strongly } \\
\text { Agree })\end{array}$ \\
\hline
\end{tabular}


Table 1 Continued

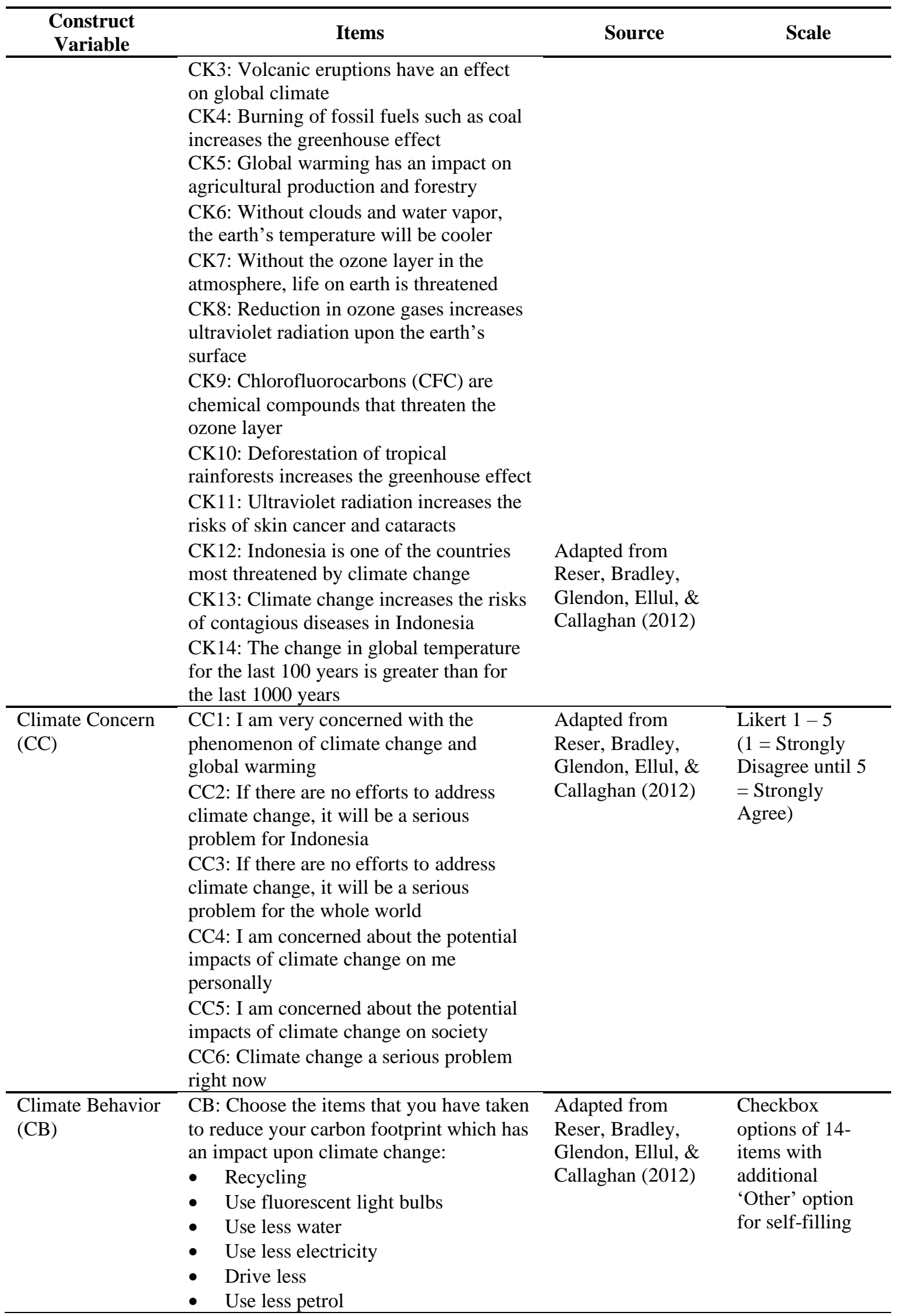


Table 1 Continued

\begin{tabular}{llll}
\hline $\begin{array}{c}\text { Construct } \\
\text { Variable }\end{array}$ & \multicolumn{1}{c}{ Items } & Source & Scale \\
\hline & $\bullet$ Walk/bike & \\
& $\bullet$ Buy local/organic/grow food & \\
& $\bullet$ Buy smaller car & \\
& $\bullet$ Reduce travel & \\
& $\bullet$ Reduce air travel & \\
& $\bullet$ Use carpool/ridesharing & \\
& Other renewable energy sources & \\
\hline
\end{tabular}

\section{Results and Discussions}

A total of 1.038 responses were recorded, of which $n=997$ were usable. Following a validity and reliability pretesting and testing, the items CK3 and CK6 was consequently dropped. Descriptive analyses were first conducted for the variable item responses, afterwards measurement model and structural model analysis to determine causal relations within the SEM conventions were done.

\section{Descriptive Analysis of Variable Item Responses}

In Table 2, it is shown that that there is a general agreeability with the 13 item climate knowledge statements (total mean of 4,267). The highest mean score being CK7 with 4,766 which points to an agreement direction. However, item CK6 showed more tendency of disagreement with a mean of 2,947 (lower than the neutral midpoint answer. Item CK13 is also relatively lower in mean responses than the other items.

Table 2. Climate Knowledge (CK) Descriptive Statistics

\begin{tabular}{lcccccc}
\hline Item & n & Min & Max & Total Score & Mean & Total Mean \\
\hline CK1 & 997 & 1 & 5 & 4306 & 4,319 & 4,267 \\
CK2 & 997 & 1 & 5 & 4672 & 4,686 & \\
CK4 & 997 & 1 & 5 & 4338 & 4,351 & \\
CK5 & 997 & 1 & 5 & 4464 & 4,477 & \\
CK7 & 997 & 1 & 5 & 4752 & 4,766 & \\
CK8 & 997 & 1 & 5 & 4463 & 4,476 & \\
CK9 & 997 & 1 & 5 & 4372 & 4,385 & \\
CK10 & 997 & 1 & 5 & 4219 & 4,232 & \\
CK11 & 997 & 1 & 5 & 4592 & 4,606 & \\
CK12 & 997 & 1 & 5 & 4126 & 4,138 & \\
CK13 & 997 & 1 & 5 & 3876 & 3,888 & \\
CK14 & 997 & 1 & 5 & 4196 & 4,209 & \\
\hline
\end{tabular}

For climate concern, Table 3 shows that there is a general agreeability with the 6 item climate concerns statements (total mean of 4,267). The highest mean score being CC3 with 4,793 which points to an agreement direction. 
Table 3. Climate Concern (CC) Descriptive Statistics

\begin{tabular}{lcccccc}
\hline Item & n & Min & Max & Total Score & Mean & Total Mean \\
\hline CC1 & 997 & 1 & 5 & 4648 & 4,662 & 4,604 \\
CC2 & 997 & 1 & 5 & 4652 & 4,666 & \\
CC3 & 997 & 1 & 5 & 4779 & 4,793 & \\
CC4 & 997 & 1 & 5 & 4366 & 4,379 & \\
CC5 & 997 & 1 & 5 & 4556 & 4,570 & \\
CC6 & 997 & 1 & 5 & 4541 & 4,555 & \\
\hline
\end{tabular}

As for the climate behaviors (CB), Figure 1 below shows that a majority of respondents engaged in walking/biking activities, with committing to use less electricity coming in second. Activities that were least popular include the use of carpool/ridesharing and use of renewable energy sources, which could be attributed to the fact that these are rarely available in Indonesia's context (with provision of renewable energy still in its infancy, and that carpooling is not a big industry yet) (Agustinus, 2017; Rezkisari, 2014).

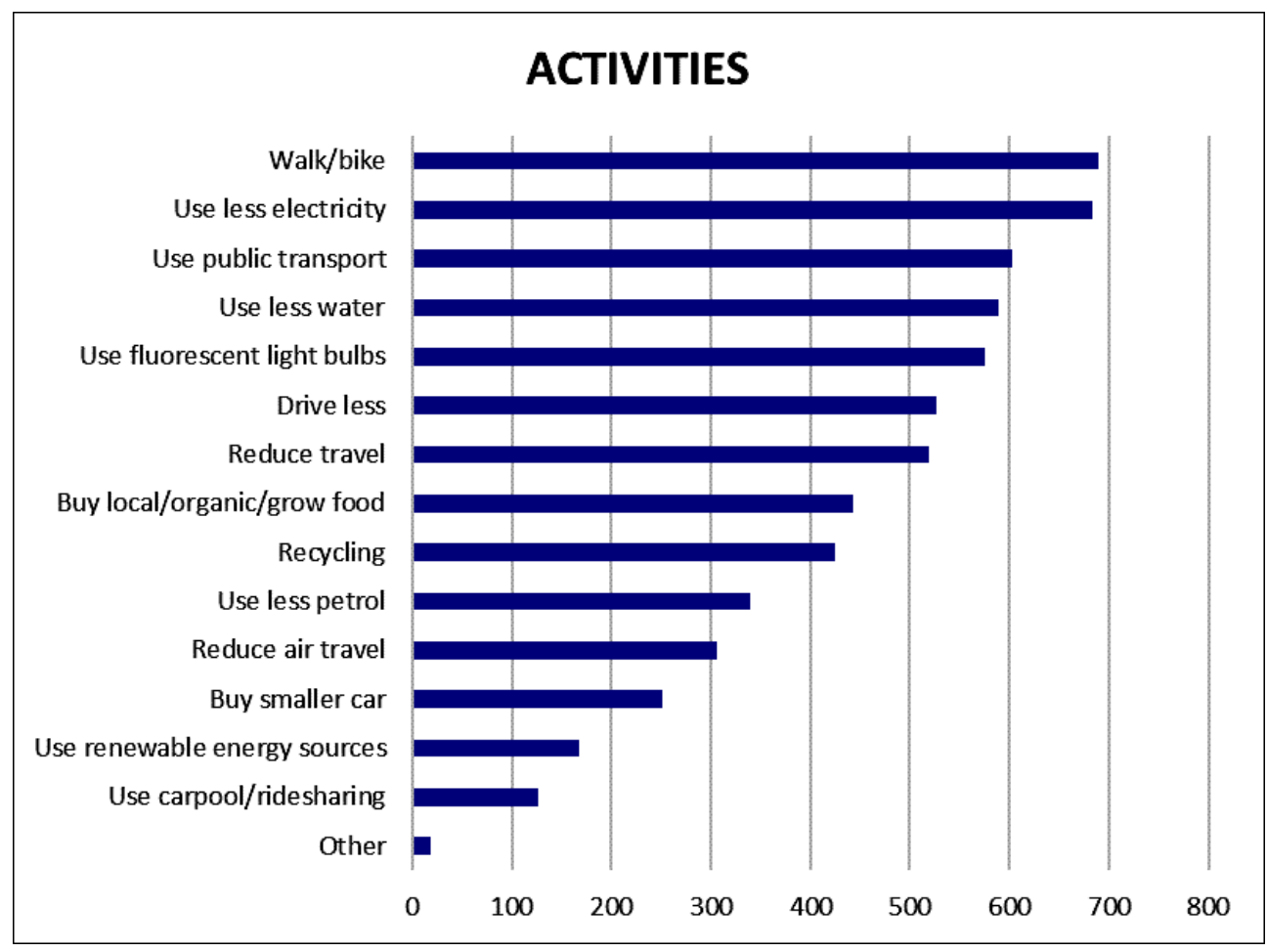

Figure 1. Respondent Activities to Reduce Carbon Footprint

Some respondents also mentioned other activities which include not using air conditioning, minimizing plastic waste, planting trees and, avoiding use of incineration for garbage disposal among others. As a measured item, the self-reported activities has a score range of $0-14$ (with 'other' being excluded). From such scoring, the average score of carbon footprint reducing activities were reported (mean $=6,262$ ). The mean figure is not far off from the reported activities of Australians measured in Reser et al., (2012) which this questionnaire is based on (mean $=6,43$ ). The difference is when looking at the activities themselves, wherein Reser et al., (2012) recorded recycling as the most popular carbon 
footprint reducing behavior. This of course to be attributed to the differing context once again, where knowledge and avenues for recycling is still at its infancy in Indonesia.

Finally, the variable value-action gap (VAG) is calculated by the standardized difference between climate concern and carbon footprint reducing activities as previously done in Chai et al., (2015) and Babutsidze et al., (2018). The variable is expressed between 1 to 1 . The formula is given as equation (1).

$$
V A G_{i}=\frac{C C_{i}}{C C_{\text {total }}}-\frac{C B_{i}}{C B_{\text {total }}}
$$

With the equation (1), climate concern's total score is 30 whilst the climate behavior is 14 . The report on the maximum, minimum and mean value-action gap scores can be found in Table 4.

Table 4. Value-Action Gap (VAG) Descriptive Statistics

\begin{tabular}{cc}
\hline & Score $(\mathbf{n}=\mathbf{9 9 7})$ \\
\hline Maximum & 0,928 \\
Minimum & $-0,347$ \\
Mean & 0,473 \\
\hline
\end{tabular}

From the Table 4, it is inferred that a gap between reported concerns and activities undertaken to reduce carbon footprint exists amongst the sample, with mean VAG score of 0,473 and standard deviation of 0,129 . There is also a recorded maximum of 0,928 , where said respondent reported only one mitigating activity despite showing concern for climate change. This number is higher than the mean score in the Australian survey at mean $=0,28$ and standard deviation $=0,24$ (Chai et al., 2015). The maximum gap scores however are similar at 0,93 . In the French sample, the value-action gap mean is lower (mean $=0,2$ ) (Babutsidze et al., 2018). Moreover, the negative scores point to an interesting direction where respondents do not report much concerns in climate change but engage in carbon footprint reducing activities (Babutsidze et al., 2018; Chai et al., 2015).

\section{Structural Model Analysis}

This sub-section details the causal relations between the latent variables as part of the structural model analysis. The hypothesis of this states whether there are relations between the variables, either positive or negative ( $\mathrm{H} 1-\mathrm{H} 7)$. Therefore, the causal relation analysis indicates the standardized loading factors from LISREL to determine the relationship, either positive or negative. Each of the relationships will be determined for significance by way of a two-tailed t-test, with confidence level of $99 \%$ and $a=0,01$. The critical value of a two-tailed t-test for $\mathrm{a}=0,01$ is $\geq 2,576$ and $\leq-2,576$ (Wijanto, 2008). If the t-values are below $-2,576$ or above 2,576 then the relations show considerably significant effect.

For direct relationships such as in $\mathrm{H} 1-\mathrm{H} 3$ and $\mathrm{H} 5-\mathrm{H} 6$, LISREL provides the output standardized loading factors and t-values. However, as $\mathrm{H} 4$ and $\mathrm{H} 7$ hypothesizes indirect relationships through mediating variables, a Sobel test is conducted to determine the tvalues. The Sobel test is given by the equation (2).

$$
t-\text { value }=\frac{a b}{\sqrt{\left(a^{2} S E_{a}^{2}\right)+\left(b^{2} S E_{b}^{2}\right)}}
$$




\section{Value-Action Gap in Climate Change Amongst Indonesians}

Where $\alpha$ is the loading factors of an exogenous variable against the mediating variable, and $b$ is the loading factors of the mediating variable against an endogenous variable. $S E$ are standard errors for both the loaded factor relations of $\alpha$ and $b$. SLF and tvalues including the interpretations for each causal relationship are outlined in Table 5.

From the table above, it can be seen that $\mathrm{H} 1$ - H6 show significance in variable relationship, whilst $\mathrm{H} 7$ is insignificant. The insignificance of $\mathrm{H} 7$ means that climate change knowledge (CK) influence upon value-action gap (VAG) via climate change concern (CC) does not show enough evidence of an effect. The direct relationship between climate change knowledge (CK) and climate change concern (CC) is positive and significant. Coefficient of determination value also indicates that $95 \%$ of variations in CC are explainable by variations in $\mathrm{CK}\left(\mathrm{R}^{2}=0,954\right)$. These results fits the theory that the more knowledgeable on the issue one gets, the more concerned one potentially can be (Babutsidze et al., 2018; Barr, 2006; Chai et al., 2015; Kennedy et al., 2009; Salehi et al., 2016).

Table 5. Standardized Loading Factors \& t-values for Model Relationships

\begin{tabular}{clccc}
\hline Hypothesis & Variable Relationship & $\begin{array}{c}\text { Standardized } \\
\text { Loading factors }\end{array}$ & t-value & Interpretation \\
\hline H1 & $\mathrm{CK} \rightarrow \mathrm{CC}$ & 0,976 & 22,817 & $\begin{array}{c}\text { Positive \& } \\
\text { Significant } \\
\text { H2 }\end{array}$ \\
CK $\rightarrow \mathrm{CB}$ & 3,554 & 9,494 & $\begin{array}{c}\text { Positive \& } \\
\text { Significant }\end{array}$ \\
$\mathrm{H} 3$ & $\mathrm{CC} \rightarrow \mathrm{CB}$ & $-3,423$ & $-9,238$ & $\begin{array}{c}\text { Negative \& } \\
\text { Significant }\end{array}$ \\
$\mathrm{H} 4$ & $\mathrm{CK} \rightarrow \mathrm{CC} \rightarrow \mathrm{CB}$ & $-3,340$ & -2.635 & $\begin{array}{c}\text { Negative \& } \\
\text { Significant }\end{array}$ \\
$\mathrm{H} 5$ & $\mathrm{CK} \rightarrow \mathrm{VAG}$ & $-5,569$ & $-6,014$ & $\begin{array}{c}\text { Negative \& } \\
\text { Significant }\end{array}$ \\
$\mathrm{H} 6$ & $\mathrm{CC} \rightarrow \mathrm{VAG}$ & 5,892 & 6,309 & $\begin{array}{c}\text { Positive \& } \\
\text { Significant } \\
\text { Positive \& }\end{array}$ \\
$\mathrm{H} 7$ & $\mathrm{CK} \rightarrow \mathrm{CC} \rightarrow \mathrm{VAG}$ & 5,750 & 1,045 & Insignificant \\
\hline
\end{tabular}

It is worth noting however, some relations show negative direction, such as $\mathrm{H} 3-\mathrm{H} 5$. For $\mathrm{H} 3$ and $\mathrm{H} 4$, the relationship between climate change concern (CC) and climate change behavior (CB) results in negative SLFs, meaning that as one increases the other decreases. This fits with the notion of discrepancy between reported concerns and climate change mitigating conduct, wherein scores of concern actually reduce behavior. On that same end, it therefore also fits that $\mathrm{H} 6$, between climate change concern $(\mathrm{CC})$ and the value action gap (VAG) shows positive significance, as heightened concern leads to lower behavior therefore increased discrepancy as indicated by VAG scores.

Yet at the same time, climate knowledge (CK) relationship with climate behavior (CB) directly is a positive one. This then leads to a negative relationship between climate change knowledge (CK) and value-action gap (VAG) which means that increased knowledge actually results in more climate change mitigating conduct (H2) and also leads to lower gap scores (H6). When taking a look at the coefficient of determination value $\left(\mathrm{R}^{2}\right)$, as indicated in the reduced form equation values from LISREL, the value of $\mathrm{R}^{2}$ between value-action gap (VAG) and climate change knowledge (CK) is 0,034, which in other words means that only $0,34 \%$ variations in VAG are explainable by variations in CK. Therefore, the rest are 
explainable by other variables. Similarly, only $0,44 \%$ of variations in climate change behavior $(\mathrm{CB})$ are explainable by variations in $\mathrm{CK}\left(\mathrm{R}^{2}=0,044\right)$.

\section{Conclusion}

The findings of this research based on the sample does suggest that varying income groups of urbanite households hold significant knowledge of climate change and have reported concerns towards the issue, and that the two as variables are linked to each other. Moreover, the same samples also reported considerable engagement in climate mitigating behaviors just as in the respondents in Australia and France (Babutsidze et al., 2018; Chai et al., 2015). At the same time, discrepancies between reported concerns and actions taken are also displayed, and that value-action gaps exists amongst the sampled group. This is also similarly explored by previous research in other countries (Babutsidze et al., 2018; Barr, 2006; Blake, 1999; Chai et al., 2015), the value-action gap just as evident in Indonesia.

In terms of policy recommendation, the suggestion is of course to address the gap itself, and given the formula there are two ways to go about it. Either through reducing the climate knowledge and concern as the formulaic numerators or increasing the climate behaviors as the denominators. The former is obviously out of the question, given the fact that wiping knowledge is unattainable and that reducing concern is all-the-more unreasonably counter-productive to the climate change agenda. The descriptive analyses (Table 2 and Table 3 ) for the constructs of climate knowledge and concern in fact suggests that there is a general agreeability with mean scores above 4 (showcasing tendency towards agreement.

That being said, the option comes down to increasing climate behaviors amongst individuals, and although clear-cut, implies a necessary change of the current consumption imperative for the nation's future. Given the consumption implications towards growth, the purpose of such growth and whether it is the only necessitating indicator for welfare improvement needs to be questioned. It is clear that voluntary efforts that begin at the homes are important for a climate safe future, yet regulatory frameworks need to be in place to enable such efforts (Dubois et al., 2019).

Moreover, research recommendations on the matter could benefit from including income variations and its effect on the levels of said discrepancy. The theoretical basis of income effects on variations of emissions have been previously laid, such as in (Büchs \& Schnepf, 2013). However, whether specifically those in higher incomes produce lessmitigating actions and whether knowledgeable and concerned attitudes are more present remains to be explored in future research. Additionally, sampling variations on larger scale could definitely strengthen future research to assess overall Indonesian's climate concerns and behaviors taken. On that same end, the inclusion of various other variables could come into play such as the complex value and cultural structures in Steg, Bolderdijk, Keizer, and Perlaviciute (2014). Inclusion of such structures may provide more contextual basis as to the underlying influences towards concern shaping, beyond the knowledge factors.

In doing so, the future research could then also go beyond the fourteen actions which are predefined as mitigating behaviors for use in the Australian, United Kingdom and French context as in Babutsidze et al., (2018); Chai et al., (2015), research can be done along the lines of improving the basket of actions availability in the Indonesian context.

\section{References}

Agustinus, M. (2017, September 15). Pasang panel surya di atap rp 15 juta, 7 tahun bisa balik modal. Detik Finance. Retrieved from: https://finance.detik.com/energi/d-3645200/pasang-panel-surya-di-atap-rp-15juta-7-tahun-bisa-balik-modal. 


\section{Value-Action Gap in Climate Change Amongst Indonesians}

Babutsidze, Z., Chai, A., Bradley, G., Nesta, L., Dietz, T., Markowitz, E., \& Hales, R. (2018). Public perceptions and responses to climate change in France. Sciences Po publications.

Bai, Y., \& Liu, Y. (2013). An exploration of residents' low-carbon awareness and behavior in Tianjin, China. Energy Policy, 61, 1261-1270. doi:10.1016/j.enpol.2013.06.014.

Barr, S. (2006). Environmental action in the home: Investigating the 'value-action' gap. Geography, 91(1), 4354. doi:10.1080/00167487.2006.12094149.

Blake, J. (1999). Overcoming the 'value-action gap' in environmental policy: Tensions between national policy and local experience. Local Environment, 4(3), 257-278. doi:10.1080/13549839908725599.

Brown, P. M., \& Cameron, L. D. (2000). What can be done to reduce overconsumption? Ecological Economics, 32(1), 27-41. doi:10.1016/S0921-8009(99)00093-2.

Büchs, M., \& Schnepf, S. V. (2013). Who emits most? Associations between socio-economic factors and UK households' home energy, transport, indirect and total CO2 emissions. Ecological Economics, 90, 114123. doi:10.1016/j.ecolecon.2013.03.007.

Chai, A., Bradley, G., Lo, A., \& Reser, J. (2015). What time to adapt? The role of discretionary time in sustaining the climate change value-action gap. Ecological Economics, 116, 95-107. doi:10.1016/j.ecolecon.2015.04.013.

Chaplin, G., \& Wyton, P. (2014). Student engagement with sustainability: understanding the value-action gap. International Journal of Sustainability in Higher Education, 15(4), 404-417. doi:10.1108/IJSHE-04-20120029.

Chung, S., \& Leung, M. (2007). The value-action gap in waste recycling: The case of undergraduates in Hong Kong. Environmental Management, 40,603-612. doi:10.1007/s00267-006-0363-y.

Dubois, G., Sovacool, B., Aall, C., Nilsson, M., Barbier, C., Herrmann, A., ... Sauerborn, R. (2019). It starts at home? Climate policies targeting household consumption and behavioral decisions are key to low-carbon futures. Energy Research \& Social Science, 52, 144-158. doi:10.1016/j.erss.2019.02.001.

Dunlap, R.E., Van Liere, K.D., Mertig, A.G. and Jones, R.E. (2000), New trends in measuring environmental attitudes: Measuring Endorsement of the new ecological paradigm: a revised NEP scale. Journal of Social Issues, 56(3), 425-442. doi:10.1111/0022-4537.00176.

Dunne, D. (2019). The carbon brief profile: Indonesia. Retrieved from: https://www.carbonbrief.org/thecarbon-brief-profile-indonesia.

Fagan, M., \& Huang, C. (2019). A look at how people around the world view climate change. Retrieved from: https://www.pewresearch.org/fact-tank/2019/04/18/a-look-at-how-people-around-the-world-viewclimate-change/.

Fishbein, M., \& Ajzen, I. (1975). Belief, Attitude, Intention, and Behavior: An Introduction to Theory and Research. Reading, MA: Addison-Wesley.

Flynn, R., Bellaby, P., \& Ricci, M. (2009). The 'value-action gap' in public attitudes towards sustainable energy: The case of hydrogen energy. The Sociological Review, 572), 159-180. doi:10.1111/j.1467954X.2010.01891.x.

GGGI-Bappenas. (2019). Membuka jalan untuk mempercepat pengembangan energi terbarukan di Indonesia. Retrieved from: http://greengrowth.bappenas.go.id/membuka-jalan-untuk-mempercepatpengembangan-energi-terbarukan-di-indonesia/.

IPCC. (2018). Global warming of $1.5^{\circ} \mathrm{C}$. Retrieved from: https://www.ipcc.ch/sr15/.

Kennedy, E., Beckley, T., Mcfarlane, B., \& Nadeau, S. (2009). Why we don't “walk the talk”: Understanding the environmental values/behaviour gap in Canada. Human Ecology Review, 16(2), 151-160.

Kline, R. B. (2015). Principles and practice of structural equation modeling (Fourth ed.). New York: The Guilford Press.

Kollmuss, A., \& Agyeman, J. (2002). Mind the gap: Why do people act environmentally and what are the barriers to pro-environmental behavior? Environmental Education Research, 8(3), 239-260. doi:10.1080/13504620220145401.

Leiserowitz, A. (2007). International public opinion, perception, and understanding of global climate change. Yale University. 
Newton, P. (2013). Exploring the attitudes-action gap in household resource consumption: Does "environmental lifestyle" segmentation align with consumer behavior? Sustainability, 5(3), 1211-1233. doi:10.3390/su5031211.

Norton, B., Costanza, R., \& Bishop, R. C. (1998). The evolution of preferences: Why `sovereign' preferences may not lead to sustainable policies and what to do about it. Ecological Economics, 24(2), 193-211. doi:10.1016/S0921-8009(97)00143-2.

Rahman, A., Hossain, M., Uddin, S., Saha, A., Hasan, K. M., \& Uddin, M. (2019). Behavioural Economics in Energy Consumption: Rational or Habitual. IOSR Journal of Humanities and Social Science, 24(4), 66-72.

Reser, J. P., Bradley, G. L., Glendon, A. I., Ellul, M. C., \& Callaghan, R. (2012). Public risk perceptions, understandings and responses to climate change in Australia and Great Britain. Retrieved from: https://research-repository.griffith.edu.au/bitstream/handle/10072/49216/84369_1.pdf.

Rezkisari, I. (2014). Hindari macet, warga Jakarta dianjurkan car pooling. Republika. Retrieved from: https://nasional.republika.co.id/berita/nasional/jabodetabek-nasional/14/12/20/ngvpdk-hindarimacet-warga-jakarta-dianjurkan-car-pooling.

Salehi, S., Nejad, Z. P., Mahmoudi, H., \& Burkart, S. (2016). Knowledge of global climate change: view of Iranian university students. International Research in Geographical and Environmental Education, 25(3), 226-243. doi:10.1080/10382046.2016.1155322.

Schahn, J., \& Holzer, E. (1990). Studies of individual environmental concern: The role of knowledge, gender, and background variables. Environment and Behavior, 22(6), 767-786. doi:10.1177/0013916590226003.

Steg, L., Bolderdijk, J. W., Keizer, K., \& Perlaviciute, G. (2014). An integrated framework for encouraging proenvironmental behaviour: The role of values, situational factors and goals. Journal of Environmental Psychology, 38, 104-115. doi:10.1016/j.jenvp.2014.01.002.

Stern, P. C. (2002). New environmental theories: Toward a coherent theory of environmentally significant behavior. Journal of Social Issues, 56(3), 407-424. doi:10.1111/0022-4537.00175.

Stokes, B., Wike, R., \& Carle, J. (2015). Global concern about climate change, broad support for limiting emissions. Washington, DC.

Thompson, S. C. G., \& Barton, M. A. (1994). Ecocentric and anthropocentric attitudes toward the environment. Journal of Environmental Psychology, 14(2), 149-157. doi:10.1016/S0272-4944(05)80168-9.

Wijanto, S. H. (2008). Structural equation modelling dengan lisrel 8.8. Yogyakarta: Graha Ilmu.

World Bank. (2009). Public attitudes toward climate change: findings from a multi-country poll. World Bank.

YouGov. (2019). YouGov-Cambridge Globalism Project. 